\title{
Kinetics of Diphtheria Toxin Formation
}

\author{
By A. M. PAPPENHEIMER Jun., PAULINE A. MILLER \\ AND MASAHIKO YONEDA* \\ The Biological Laboratories, Harvard University, Cambridge, Massachusetts, U.S.A.
}

(Received 20 September 1961)

\begin{abstract}
SUMMARY
Studies on the kinetics of diphtheria toxin formation in iron-free culture media by variants of the PW no. 8 strain of Corynebacterium diphtheriae labelled with ${ }^{14} \mathrm{C}$-phenylalanine or ${ }^{35} \mathrm{~S}$-methionine, showed that the toxin protein was synthesized de novo from amino acids by growing organisms. Release of toxin into the extracellular medium occurred without lysis of more than a minor proportion of the bacterial population.
\end{abstract}

\section{INTRODUCTION}

Diphtheria toxin is only synthesized by strains of Corynebacterium diphtheriae which are lysogenic for a particular bacteriophage or one of its mutants (Freeman, 1951; Groman, 1953; Barksdale, 1955) and which are growing under conditions of decreasing bacterial iron content (Pappenheimer, 1955). The toxin is released into the external culture medium as it is formed during the terminal stages of growth, and at any given time, only traces can be extracted from the bacteria themselves (Raynaud, Turpin, Mangalo \& Bizzini, 1954). While there seems to be general agreement that the genetic information which controls toxin synthesis is carried by the prophage, the exact relationship between phage and toxin formation has not been established. Barksdale and his co-workers (Barksdale, 1959; Barksdale, Garmise \& Horibata, 1960; Barksdale, Garmise \& Rivera; 1961) presented evidence which suggests that under certain conditions at least, induction of prophage to the vegetative state by ultraviolet (u.v.) radiation may accelerate the release of toxin and enhance its yield several fold. These authors suggested that under the usual conditions for producing toxin, its formation may be a consequence of 'autoinduction' and phage multiplication resulting from a decreased bacterial iron content. Barksdale et al. (1961) observed a steady decline in viable count during toxin production in cultures of a variant of the PW no. 8 strain of C. diphtheriae. Unfortunately, this strain has been reported to carry a 'defective' prophage which does not give rise to plaque-forming particles following induction (Barksdale, 1959) so that it was not possible for them to establish a direct relationship between the decrease in viable count and phage multiplication.

From the earlier work by Barksdale \& Pappenheimer (1954), Hatano (1956), Yoneda \& Pappenheimer (1957), Yoneda (1957a), Edwards (1960) and others, it seems most unlikely that the liberation of toxin is associated with the lysis of any significant fraction of the bacterial population. Nevertheless, because of the recent suggestion that phage multiplication may be directly involved in toxin production,

* Present address : Research Institute for Microbial Diseases, Osaka University, Osaka, Japan. 


\section{A. M. Pappenheimer Jun., P. A. Miller and M. Yoneda}

it seemed to us worthwhile to re-investigate the kinetics of toxin formation as a function of bacterial growth and lysis. In the present work we have followed toxin production by organisms of $C$. diphtheriae $\mathrm{PW}$ no. 8 strains labelled with ${ }^{35} \mathrm{~S}-\mathrm{methio-}$ nine and ${ }^{14} \mathrm{C}$-phenylalanine growing in an iron-free unlabelled medium. The results have shown conclusively that toxin is synthesized de novo from amino acids and that its liberation into the extracellular medium is not associated to any significant degree with bacterial lysis.

\section{METHODS}

Organisms. Variants of the classic Park-Williams strain of Corynebacterium diphtheriae were used including the SM-1 strain of Yoneda $(1957 b)$ and the rough and smooth strains, PW no. $8_{\mathrm{r}}(\mathrm{Pd})$ and $\mathrm{PW}$ no. $\mathbf{8}_{\mathrm{s}}(\mathrm{Pd})$, kindly sent us by $\mathrm{Dr} \mathrm{W}$. L. Barksdale.

Culture media and toxin production. The $\mathrm{PW}$ no. $8(\mathrm{Pd})$ strains were grown on the casein hydrolysate medium of Mueller \& Miller (1941). SM-1 was grown on the AMC medium of Yoneda (1957 $b$ ). For toxin production the organisms were grown overnight on media supplemented with $0 \cdot 1 \mu \mathrm{g} \cdot / \mathrm{ml}$. $\mathrm{FeSO}_{4} \cdot \mathbf{7} \mathbf{H}_{2} \mathrm{O}$ and $2 \%(\mathrm{w} / \mathrm{v})$ maltose to an optical density (OD) at $(590 \mathrm{~m} \mu)$ of $2-2 \cdot 5$. The culture was centrifuged and the bacteria washed with iron-free medium and resuspended to OD $=5-6$ in iron-free medium containing $4 \%(\mathrm{w} / \mathrm{v})$ iron-free maltose as described by Yoneda $(1957 b)$. In all experiments the organisms were grown on a rotating shaking machine at 33-35 ${ }^{\circ}$.

Growth was followed by measuring optical density at $590 \mathrm{~m} \mu$, of samples diluted in distilled water, in a Bausch and Lomb Spectronic 20 and by dry-weight determinations. Dry weight was determined by filtration of suitable samples (5 or $10 \mathrm{ml}$.) on weighed Millipore filters. The bacteria were washed thoroughly on the filter with distilled water and then dried to constant weight. An OD of 1.0 was found to correspond to $0.47 \pm 0.02 \mathrm{mg}$. dry weight bacteria $/ \mathrm{ml}$.

Amino acids. ${ }^{35} \mathrm{~S}-\mathrm{L}-\mathrm{methionine}$ was obtained from Abbot Laboratories; ${ }^{14} \mathrm{C}-\mathrm{L}-$ phenylalanine from Oak Ridge Laboratories. Radioactivity was measured in a low background (2.7 counts/min.) windowless gas counter (Nuclear Chicago).

Antitoxin. The rapidly flocculating pepsin-treated horse antitoxin no. 5353A was used. This antitoxin precipitates toxin completely over a broad zone (Pappenheimer \& Yoneda, 1957) and has been shown to give only one band of precipitate on immuno-electrophoresis (Raynaud \& Relyveld, 1959).

Fumarase was determined spectrophotometrically at $24^{\circ}$ by following the rate of fumarate formation from malate at $240 \mathrm{~m} \mu$ according to the method of Racker (1950).

Coproporphyrin III was determined by adsorption on alumina at pH 5 followed by elution with $\mathrm{N}-\mathrm{HCl}$ as described by Yoneda \& Pappenheimer (1957). Porphyrin concentration was calculated from the extinction at $403 \mathrm{~m} \mu$, assuming a molar extinction coefficient of $5 \cdot 3 \times 10^{5}$ (Jope \& O'Brien, 1945). 


\section{RESULTS \\ Toxin production and growth}

A $500 \mathrm{ml}$. culture of Corynebacterium diphtheriae $\mathrm{PW}$ no. $8_{\mathrm{r}}(\mathrm{Pd})$ was grown overnight on casein hydrolysate medium to $O D=2 \cdot 5$. It was centrifuged, washed twice with iron-free medium and resuspended in $200 \mathrm{ml}$. iron-free medium containing $4 \%(\mathrm{w} / \mathrm{v})$ maltose. After a homogeneous suspension had been obtained by shaking at $35^{\circ}$ for $45 \mathrm{~min}$., $100 \mathrm{ml}$. portions were placed in two 1 l. flasks. Samples were removed immediately from each flask and at intervals thereafter for determination of optical density, $\mathrm{pH}$ value and dry weight of organisms. Porphyrin and toxin were determined in the bacteria free filtrate. The final yields of toxin in the two flasks after $30 \mathrm{hr}$. shaking at $35^{\circ}$ were 116 and $108 \mathrm{Lf} / \mathrm{ml}$., respectively. Table 1 shows that optical density and bacterial mass, as measured by dry weight, were strictly proportional over the entire $30 \mathrm{hr}$. period. Coproporphyrin release at a linear rate began almost immediately after the bacteria were suspended in the ironfree medium. Toxin appeared in the filtrate soon afterward and increased at a maximum rate over a $15 \mathrm{hr}$. period during which the bacterial mass nearly doubled. A net increase in bacterial dry weight of $4.7 \mathrm{mg}$. was associated with the liberation of approximately $250 \mu \mathrm{g}$. toxin protein (about $5 \%$ by weight).

Table 1. Relation of optical density to dry weight during toxin production by Corynebacterium diphtheriae strain $P W$ no. $8_{\mathrm{r}}(\mathrm{Pd})$

\begin{tabular}{|c|c|c|c|c|}
\hline $\begin{array}{l}\text { Time } \\
\text { (hr.) }\end{array}$ & $\begin{array}{c}\text { Optical* } \\
\text { density at } \\
540 \mathrm{~m} \mu\end{array}$ & $\begin{array}{l}\text { Dry weight* } \\
\text { (mg./ml.) }\end{array}$ & $\begin{array}{c}\text { Porphyrin* } \\
(\mathrm{m}-\mathrm{mole} \\
\left.\times 10^{-2} / \mathrm{ml} .\right)\end{array}$ & $\begin{array}{l}\text { Toxin* } \\
\text { (Lf/ml.) }\end{array}$ \\
\hline 0.75 & $6 \cdot 0$ & $3 \cdot 10$ & $0 \cdot 019$ & Not done \\
\hline $3 \cdot 75$ & $7 \cdot 6$ & $4 \cdot 50$ & $0 \cdot 132$ & Not done \\
\hline $6 \cdot 25$ & $11 \cdot 2$ & 5.89 & $0 \cdot 381$ & $5-7 \cdot 5$ \\
\hline 10.5 & - & $7 \cdot 32$ & 0.587 & 35 \\
\hline $22 \cdot 25$ & $21 \cdot 0$ & $10 \cdot 55$ & 1.21 & 108 \\
\hline $28 \cdot 25$ & 25.5 & $11 \cdot 6$ & $1 \cdot 13$ & 100 \\
\hline 30.75 & $22 \cdot 0$ & 12.5 & 1.38 & 116 \\
\hline
\end{tabular}

* Figures given average of determinations on duplicate flasks.

\section{Fumarase synthesis during growth on iron-deficient medium}

An overnight culture of Corynebacterium diphtheriae PW no. $8_{\mathbf{g}}(\mathrm{Pd})$ was centrifuged, washed with iron-free medium and resuspended in the same medium containing $4 \%(\mathrm{w} / \mathrm{v})$ maltose to $\mathrm{OD}=\mathbf{5} \cdot \mathbf{0}$. The culture was incubated with shaking at $35^{\circ}$, samples were removed at intervals over a $22 \mathrm{hr}$. period and their OD determined. Samples $(3 \mathrm{ml}$.) were diluted to exactly $15 \mathrm{ml}$. in $0.02 \mathrm{M}$-phosphate buffer (pH 7.4) and disrupted for $10 \mathrm{~min}$. in the $10 \mathrm{kc}$ Raytheon sonic oscillator. It was observed that as the bacterial iron content decreased in successive samples, the organisms became progressively more fragile and more easily broken by ultrasonic disintegration. After $22 \mathrm{hr}$. the culture filtrate contained $70 \mathrm{Lf}$ toxin/ml. Figure 1 shows that fumarase, an enzyme which does not contain iron, increased about fivefold during the $22 \mathrm{hr}$. period in proportion to the increase in bacterial mass as measured by OD. Thus the bacteria were able to form new cellular protein at a 


\section{A. M. Pappenhermer Jun., P. A. Miller and M. Yoneda}

constant differential rate of synthesis during toxin production. This result would hardly be expected if toxin were released either by autolysis or by phage lysis of a major proportion of the bacterial population.

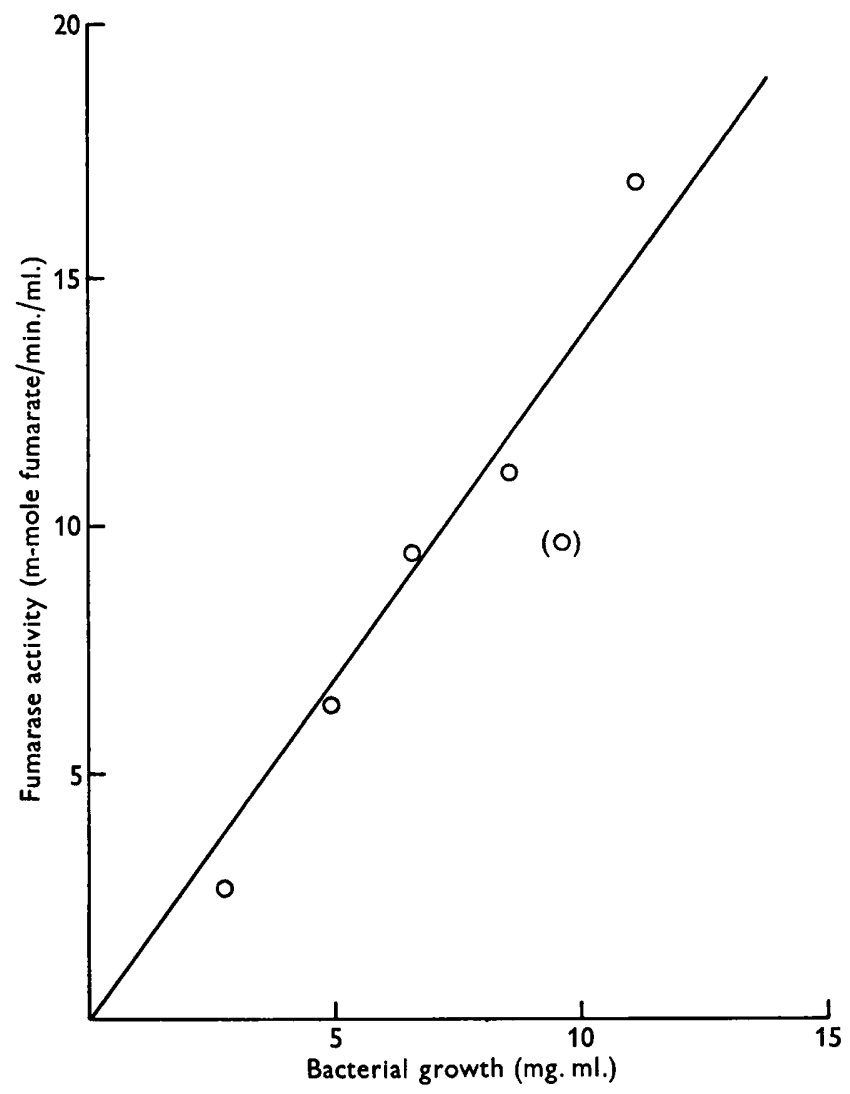

Fig. 1. Fumarase formation in Fe-free medium by Corynebacterium diphtheriae PW no. $8_{8}$ strain. The final yield of toxin in this experiment was $70 \mathrm{Lf} / \mathrm{ml}$.

\section{Toxin production from ${ }^{35} \mathrm{~S}$-methionine-labelled bacteria}

The SM-1 variant of Corynebacterium diphtheriae PW no. 8 is exacting for L-methionine. Organisms washed with methionine-free AMC medium (Yoneda, $1957 b$ ) were inoculated to $O D=0.1$ in $200 \mathrm{ml}$. AMC medium containing $2 \%(\mathrm{w} / \mathrm{v})$ maltose, $0 \cdot 1 \mu \mathrm{g}$. $\mathrm{FeSO}_{4} \cdot 7 \mathrm{H}_{2} \mathrm{O} / \mathrm{ml}$. and $50 \mu \mathrm{g}$. ${ }^{35} \mathrm{~S}-\mathrm{L}-\mathrm{Methionine}$ (specific activity = 2520 counts $/ \mathrm{min} . / \mu \mathrm{g}$.) per $\mathrm{ml}$. After growth for $15 \mathrm{hr}$. at $35^{\circ}$, the culture was harvested, centrifuged in the cold and washed twice with chilled iron-free medium containing no methionine. The labelled bacteria were then thoroughly resuspended in $125 \mathrm{ml}$. iron-free AMC medium containing $4 \%(w / v)$ maltose, and $200 \mu \mathrm{g}$. unlabelled L-methionine $/ \mathrm{ml}$. The homogeneous bacterial suspension $(O D=4 \cdot 3)$ giving 48,000 counts $/ \mathrm{min}$. $/ \mathrm{ml}$. was distributed in $30 \mathrm{ml}$. amounts into four $300 \mathrm{ml}$. Erlenmeyer flasks and incubated at $33^{\circ}$. After 1, 2, 4 and $6 \mathrm{hr}$. of incubation a flask was removed from the shaking machine, the $O D$ measured and the bacteria removed by centrifugation at $5000 \mathrm{rev} . / \mathrm{min}$. in the Servall SS-2 for $\mathbf{3 0} \mathrm{min}$. After determining 
the flocculation titre of the supernatant fluid, the toxin was quantitatively precipitated by antitoxin, from each of two $10 \mathrm{ml}$. samples. To the first sample the calculated amount of antitoxin was added. To the second sample an amount of purified unlabelled toxin was added sufficient to bring the total to $400 \mathrm{Lf}$, followed by the addition of $1 \mathrm{ml}$. antitoxin 5353 $\mathrm{AD}$ (440 units $/ \mathrm{ml}$.). The flocculation mixtures were placed in the water bath at $40^{\circ}$ for $1 \mathrm{hr}$. and then left overnight in the cold. The specific precipitates were collected by centrifugation and washed with chilled saline until no radioactivity could be detected in the supernatant fluids. The precipitates were then dissolved and made up to exactly $2 \mathrm{ml}$. in $0.25 \mathrm{~N}$-acetic acid and $0.1 \mathrm{ml}$. samples were placed on planchets, dried and counted.

Table 2. Toxin production by ${ }^{35} S$-methionine-labelled Corynebacterium diphtheriae strain $P W$ no. $8 S M-1$ variant

\begin{tabular}{|c|c|c|c|c|c|c|}
\hline $\begin{array}{l}\text { Time } \\
\text { (hr.) }\end{array}$ & $\begin{array}{l}\text { Growth* } \\
\text { (OD 590) }\end{array}$ & $\begin{array}{l}\text { Total toxin } \\
\text { in } 10 \mathrm{ml} . \\
\text { sample } \\
\text { (Lf) }\end{array}$ & $\begin{array}{l}\text { Unlabelled } \\
\text { toxin } \\
\text { added } \\
\text { (Lf) }\end{array}$ & $\begin{array}{c}\text { Specifically } \\
\text { precipitable } \\
\text { methionine } \\
\text { (counts/min.) }\end{array}$ & $\begin{array}{l}{ }^{96} \mathrm{~S}- \\
(\mu \mathrm{g} .)\end{array}$ & $\begin{array}{c}\text { Total } \\
\text { methionine } \\
\text { precipitated } \dagger \\
(\mu \mathrm{g} .)\end{array}$ \\
\hline 1 & $5 \cdot 9$ & $\begin{array}{l}\mathbf{5 0} \\
\mathbf{5 0}\end{array}$ & $\begin{array}{r}350 \\
0\end{array}$ & $\begin{array}{l}4,12 \\
4112\end{array}$ & $\begin{array}{l}0 \cdot 16 \\
0 \cdot 16\end{array}$ & $\begin{array}{l}1.77 \\
1.77\end{array}$ \\
\hline 2 & $8 \cdot 3$ & $\begin{array}{l}100 \\
100\end{array}$ & $\begin{array}{r}300 \\
0\end{array}$ & $\begin{array}{l}800 \\
368\end{array}$ & $\begin{array}{l}0.32 \\
0 \cdot 15\end{array}$ & $\begin{array}{l}3 \cdot 54 \\
3 \cdot 54\end{array}$ \\
\hline 4 & $10 \cdot 0$ & $\begin{array}{l}200 \\
200\end{array}$ & $\begin{array}{r}200 \\
0\end{array}$ & $\begin{array}{l}595 \\
440\end{array}$ & $\begin{array}{l}0.24 \\
0 \cdot 17\end{array}$ & $\begin{array}{l}7 \cdot 08 \\
7 \cdot 08\end{array}$ \\
\hline 6 & 12.5 & $\begin{array}{l}\mathbf{3 5 0} \\
\mathbf{3 5 0}\end{array}$ & $\begin{array}{r}50 \\
0\end{array}$ & $\begin{array}{l}595 \\
453\end{array}$ & $\begin{array}{l}0 \cdot 24 \\
0 \cdot 18\end{array}$ & $\begin{array}{l}13 \cdot 2 \\
13 \cdot 2\end{array}$ \\
\hline
\end{tabular}

* Washed bacteria inoculated at time zero to $\mathrm{OD}=4 \cdot 3$ and 48,000 counts ${ }^{35} \mathrm{~S}-$ methionine/ $\mathrm{min} . / \mathrm{ml}$. into Fe-free medium containing $200 \mu \mathrm{g}$. unlabelled L-methionine.

$\dagger$ Calculated, assuming $2 \cdot 44 \mu \mathrm{g}$. toxin protein $/ \mathrm{Lf}$ and a methionine content of $1.45 \%$.

The results are given in Table 2. It will be noted that from $10 \mathrm{ml}$. of culture of ${ }^{35} \mathrm{~S}$-labelled bacteria giving a total of 480,000 counts $/ \mathrm{min}$. (190 $\mu \mathrm{g}$. methionine) only 400-600 counts/min., equivalent to $0 \cdot 16-0 \cdot 24 \mu \mathrm{g}$. methionine, were specifically precipitable from the supernatant by antitoxin. The methionine content of diphtheria toxin is approximately $1 \cdot 45 \%$ (Pappenheimer \& Yoneda, 1957). Assuming 2.44 $\mu \mathrm{g}$. protein /Lf, it can be calculated that of the $5 \mathbf{~ L f}$ toxin $/ \mathrm{ml}$. liberated during the first hour, only $0.45 \mathrm{Lf} / \mathrm{ml}$. or $9 \%$ was labelled. This amount of toxin might well have been preformed and carried over with the inoculum, or formed from an ${ }^{35} \mathrm{~S}$-methionine pool carried over with the inoculum. Over the next few hours, there was little or no increase in the specifically precipitable ${ }^{35} \mathrm{~S}$ and of the $35 \mathrm{Lf}$ toxin $/ \mathrm{ml}$. released during the entire $6 \mathrm{hr}$. period only $2 \%$ or less contained the label.

\section{Toxin production from ${ }^{14} \mathrm{C}$-labelled bacteria}

The SM-1 variant of Corynebacterium diphtheriae PW no. 8 strain does not require phenylalanine for its growth. However, in the presence of an excess of ${ }^{14} \mathrm{C}$-phenylalanine, bacterial synthesis of this amino acid is repressed and the organisms take up, during growth, an amount of ${ }^{14} \mathrm{C}$ equivalent to a phenylalanine content of about $2.5 \%$.

A culture of the SM-1 strain was inoculated to OD $=0.1$ in $400 \mathrm{ml}$. AMC medium containing $0 \cdot 1 \mu \mathrm{g}$. $\mathrm{FeSO}_{4} \cdot 7 \mathrm{H}_{2} \mathrm{O} / \mathrm{ml} ., 2 \%(\mathrm{w} / \mathrm{v})$ maltose and $24 \mu \mathrm{g} .{ }^{14} \mathrm{C}-\mathrm{L}-$ phenylalanine 


\section{A. M. Pappenheimer Jun., P. A. MmLer and M. Yoneda}

(specific activity $=350$ counts $/ \mathrm{min} . / \mu \mathrm{g}$.) $/ \mathrm{ml}$. After shaking for $16 \mathrm{hr}$. at $34^{\circ}$, the culture had reached $O D=1.9$. It was centrifuged and washed once with $100 \mathrm{ml}$. iron-free AMC medium containing no phenylalanine. The washed organisms were homogenized and resuspended in chilled iron-free medium containing $4 \%(\mathrm{w} / \mathrm{v})$ maltose and divided into two equal portions, $A$ and $B$, of $86 \mathrm{ml}$. each. To A was added $3 \mathrm{ml}$. of $0.8 \%(\mathrm{w} / \mathrm{v}){ }^{14} \mathrm{C}-\mathrm{L}$-phenylalanine $(350$ counts $/ \mathrm{min} . / \mu \mathrm{g}$.$) and the culture$ distributed into four $125 \mathrm{ml}$. Erlenmeyer flasks: $25 \mathrm{ml}$. in A1 and A2, $20 \mathrm{ml}$. in A3 and A4. To B was added $3 \mathrm{ml}$. of $1 \%(\mathrm{w} / \mathrm{v})$ unlabelled phenylalanine and the culture distributed as in series A. All eight flasks were placed on the shaking machine and incubated at $34^{\circ}$. At 1, 2, 4 and $7 \mathrm{hr}$., one flask from each series was removed. After determining the $\mathrm{OD}$, duplicate $0.5 \mathrm{ml}$. samples were filtered through Millipore filters and the bacteria washed thoroughly on the filter with ice-cold $5 \%$ $(\mathrm{w} / \mathrm{v})$ trichloroacetic acid containing $150 \mu \mathrm{g}$. unlabelled phenylalanine $/ \mathrm{ml}$. The filters were glued to planchets, dried and counted. The remainder of each culture was centrifuged at $5000 \mathrm{rev} . / \mathrm{min}$. for $20 \mathrm{~min}$. in the cold and the supernatant fluid filtered through a Millipore filter. Duplicate $0.1 \mathrm{ml}$. samples of filtrates from series B were placed on planchets, dried and counted. Flocculation tests on the $4 \mathrm{hr}$. filtrates showed $10 \mathrm{Lf} / \mathrm{ml}$. (A3 and B3) and at $7 \mathrm{hr}$., $22 \mathrm{Lf} / \mathrm{ml}$. (A4 and B4).

Table 3. Growth and lysis of bacteria labelled with ${ }^{14} \mathrm{C}$-phenylalanine in $\mathrm{Fe}$-free medium containing phenylalanine

Organisms: Corynebacterium diphtheriae, PW no. 8 strain, SM-1 variant

\begin{tabular}{|c|c|c|c|c|c|}
\hline \multirow[b]{2}{*}{$\begin{array}{l}\text { Flask } \\
\text { no.* }\end{array}$} & \multirow[b]{2}{*}{$\begin{array}{l}\text { Time } \\
\text { (hr.) }\end{array}$} & \multirow{2}{*}{$\begin{array}{l}\text { Bacterial } \\
\text { growth } \\
\text { (mg. dry } \\
\text { wt./ml.) } \dagger\end{array}$} & \multicolumn{2}{|c|}{ Bacterial ${ }^{14} \mathrm{C}$} & \multirow{2}{*}{$\begin{array}{l}\text { Supernate } \\
\text { (Counts/ } \\
\text { min./ml.) }\end{array}$} \\
\hline & & & $\begin{array}{l}\text { (Counts/ } \\
\text { min./ml.) }\end{array}$ & $\begin{array}{c}\text { (Counts/min./ } \\
\text { mg. dry wt.) }\end{array}$ & \\
\hline $\begin{array}{l}\mathbf{A}_{0} \\
\mathbf{B}_{0}\end{array}$ & $\mathbf{0}$ & $\begin{array}{l}(2 \cdot 0) \S \\
(2 \cdot 0)\end{array}$ & $\begin{array}{l}(7400) \\
(7400)\end{array}$ & $\begin{array}{l}(3700) \\
(3700)\end{array}$ & $\begin{array}{r}94,000 \\
(59)\end{array}$ \\
\hline $\begin{array}{l}\mathbf{A}_{1} \\
\mathbf{B}_{1}\end{array}$ & $\mathbf{1}$ & $\begin{array}{l}2 \cdot 40 \\
2 \cdot 40\end{array}$ & $\begin{array}{l}9970 \\
7225\end{array}$ & $\begin{array}{l}4170 \\
3000\end{array}$ & $\overline{107}$ \\
\hline $\begin{array}{l}\mathbf{A}_{2} \\
\mathbf{B}_{2}\end{array}$ & 2 & $\begin{array}{l}2 \cdot 86 \\
2 \cdot 86\end{array}$ & $\begin{array}{r}11,000 \\
7030\end{array}$ & $\begin{array}{l}3850 \\
2460\end{array}$ & $\overline{151}$ \\
\hline $\begin{array}{l}\mathbf{A}_{3} \\
\mathbf{B}_{3}\end{array}$ & 4 & $\begin{array}{l}3 \cdot 41 \\
3 \cdot 41\end{array}$ & $\begin{array}{r}15,000 \\
6630\end{array}$ & $\begin{array}{l}4400 \\
1940\end{array}$ & $\overline{261}$ \\
\hline $\begin{array}{l}\mathbf{A}_{\mathbf{4}} \\
\mathbf{B}_{\mathbf{4}}\end{array}$ & 7 & $\begin{array}{l}4 \cdot 14 \\
4 \cdot 14\end{array}$ & $\begin{array}{r}19,300 \\
6630\end{array}$ & $\begin{array}{l}4650 \\
1600\end{array}$ & $\overline{392}$ \\
\hline
\end{tabular}

* A, 270 $\mu$ g. ${ }^{14} \mathrm{C}-\mathrm{L}-$ phenylalanine $\left(9 \cdot 4 \times 10^{4}\right.$ counts $\left./ \mathrm{min} . / \mathrm{ml}.\right) / \mathrm{ml} . \mathrm{B}, 340 \mu \mathrm{g}$. unlabelled L-phenylalanine/ml.

$\dagger$ Calculated from OD assuming $0.47 \mathrm{mg}$. dry wt./OD unit.

$\ddagger$ Corrected for self absorption; actual count $32 \%$ lower.

$\S$ Zero time values in parentheses by extrapolation.

Table 3 shows that from a bacterial inoculum containing 7400 counts $/ \mathrm{min} . / \mathrm{ml}$, only 285 counts $/ \mathrm{min}$. $/ \mathrm{ml}$. (corrected for self absorption) were released into the supernatant fluid during the $6 \mathrm{hr}$. which elapsed between the first and last samples in series B, equivalent to the lysis of less than $4 \%$ of the initial bacterial suspension. In other words, if toxin were released by lysis of the initial bacterial suspension, the $55 \mu \mathrm{g}$. unlabelled toxin released into the external medium during the course of the experiment (see Table 4) must have been derived from only $80 \mu \mathrm{g}$. labelled organisms. Toxin, therefore, is not a product of cell lysis. 
Toxin was precipitated quantitatively and specifically from duplicate $10 \mathrm{ml}$. samples of culture filtrates from flasks incubated for 1 and $2 \mathrm{hr}$. and from duplicate $5 \mathrm{ml}$. samples from the 4 and $7 \mathrm{hr}$. filtrates. An amount of purified unlabelled toxin (370 Lf/ml.; $2 \cdot 5 \mu \mathrm{g}$. protein $/ \mathrm{ml}$.) was added to each sample so as to bring the total Lf content to approximately $200 \mathrm{Lf}$, and then 200 units of antitoxin added. In the case of the $7 \mathrm{hr}$. filtrates (A 4, B 4) unlabelled toxin was added only to one sample: the other $5 \mathrm{ml}$. sample was precipitated by 100 units of antitoxin without blending. The flocculation mixtures were placed in the water bath at $40^{\circ}$ for $1 \mathrm{hr}$. and then left overnight in the cold. They were centrifuged and washed 3 times with chilled saline containing $0 \cdot 1 \%(\mathrm{w} / \mathrm{v})$ unlabelled phenylalanine. The washed floccules were suspended in $1 \mathrm{ml}$. saline and the precipitate completely dissolved by addition of

\section{Table 4. Toxin production by bacteria labelled with ${ }^{14} C$-phenylalanine}

Organism: Corynebacterium diphtheriae, strain PW, no. 8, SM-1 variant. The inoculum was equiv. $2 \cdot 1 \mathrm{mg}$. dry wt. ${ }^{14} \mathrm{C}$-bacteria/ml. giving 7400 counts $/ \mathrm{min} . / \mathrm{ml}$. in Fe-free medium. A, $270 \mu \mathrm{g} . / \mathrm{ml}$. ${ }^{14} \mathrm{C}$-phenylalanine $\left(9.4 \times 10^{4}\right.$ counts $/ \mathrm{min} . / \mathrm{ml}$.) $\mathrm{B}, 340 \mu \mathrm{g} . / \mathrm{ml}$. unlabelled phenylalanine.

\begin{tabular}{|c|c|c|c|c|c|c|}
\hline \multirow{2}{*}{$\begin{array}{l}\text { Time } \\
\text { (hr.) }\end{array}$} & \multirow{2}{*}{$\begin{array}{c}\text { Bacterial } \\
\text { growth } \\
\text { (mg. dry wt. } \\
\text { organism/ml.) }\end{array}$} & \multirow{2}{*}{$\begin{array}{c}\text { Total } \\
\text { toxin } \\
(\mathbf{L f} / \mathrm{ml} .)\end{array}$} & \multicolumn{2}{|c|}{$\begin{array}{c}\text { Specifically } \\
\text { precipitable }{ }^{14} \mathrm{C} \\
\text { (counts/min./ml.) }\end{array}$} & \multicolumn{2}{|c|}{$\begin{array}{l}{ }^{14} \text { C-Toxin* } \\
\text { (Lf/ml.) }\end{array}$} \\
\hline & & & $\mathbf{A}$ & $\mathbf{B}$ & $\mathbf{A}$ & $\mathbf{B}$ \\
\hline 1 & $2 \cdot 40$ & - & 19 & $2 \cdot 3$ & 0.9 & $0 \cdot 11$ \\
\hline 2 & $2 \cdot 86$ & - & 78 & $3 \cdot 5$ & $\mathbf{3} \cdot \mathbf{7}$ & 0.17 \\
\hline 4 & 3.41 & 10 & 217 & 6.9 & $10 \cdot 3$ & 0.33 \\
\hline 7 & $4 \cdot 14$ & 22 & 458 & 6.9 & $21 \cdot 8$ & 0.33 \\
\hline
\end{tabular}

$2.5 \mathrm{ml}$. cold $5 \%(\mathrm{w} / \mathrm{v})$ trichloroacetic acid containing $150 \mu \mathrm{g}$. unlabelled phenylalanine $/ \mathrm{ml}$. After a few minutes at room temperature, the precipitate reformed and after a further 30-60 min. was collected on Millipore filters, washed with $5 \%(\mathrm{w} / \mathrm{v})$ trichloroacetic acid, dried and counted. The results given in Table 4 are averages of duplicate determinations agreeing within $5 \%$ in every case. From the radioactivity specifically precipitable by antitoxin from the 4 and $7 \mathrm{hr}$. samples, it is easily calculated that the toxin formed in the A series contained 21 counts/min./Lf. Assuming that phenylalanine synthesis was completely repressed by the excess labelled phenylalanine, a specific activity of 350 counts $/ \mathrm{min} . / \mu \mathrm{g}$. phenylalanine and $2 \cdot 44 \mu \mathrm{g}$. protein $/ \mathrm{Lf}$, the phenylalanine content of diphtheria toxin is calculated to be $2.5 \%$. (The concentration of ${ }^{14} \mathrm{C}$-phenylalanine $(24 \mu \mathrm{g} . / \mathrm{ml}$.) used to prepare the labelled inoculum was sufficient to repress bacterial synthesis of this amino acid by only $40-50 \%$. The presence of a large excess of phenylalanine in the iron-free medium, giving almost complete repression, accounts for the increasing ${ }^{14} \mathrm{C}$ content of the bacteria in series A during the course of toxin production; column 5, Table 3 ). From the counts specifically precipitated from A1 and A2 filtrates, the toxin synthesized after growth for 1 and $2 \mathrm{hr}$. is calculated to be 0.9 and $3.7 \mathrm{Lf} / \mathrm{ml}$., respectively.

Turning to the $B$ series, we find that from a bacterial inoculum containing 7400 counts phenylalanine $/ \mathrm{min} . / \mathrm{ml}$., only $2 \cdot 3$ counts specifically precipitable ${ }^{14} \mathrm{C} / \mathrm{min} . / \mathrm{ml}$. was released into the culture filtrate during the first hour of growth. This small 


\section{A. M. Pappenhetmer Jun., P. A. Miller and M. Yoneda}

amount of labelled toxin (equivalent to only $0 \cdot 1 \mathrm{Lf}$ in series A) might well have been transferred with the inoculum. After $7 \mathrm{hr}$. the culture filtrate still contained only 6.9 counts specifically precipitable ${ }^{14} \mathrm{C} / \mathrm{min}$. $/ \mathrm{ml}$. Thus, at most, $1.5-3 \%$ of the toxin released during the experiment was labelled, and the remainder must have been synthesized from unlabelled phenylalanine by bacteria actively growing on the iron-free medium. This result agrees well with that obtained in the previous experiment with bacteria labelled with ${ }^{35} \mathrm{~S}$-methionine.

\section{DISCUSSION}

It is clear from the results presented that in an iron-free culture medium, diphtheria toxin is produced by growing bacteria. During the period when toxin is being released, the bacterial mass increases several fold, whether measured by optical density, dry weight or by the synthesis of a protein enzyme, fumarase. Whether or not the fourfold to fivefold increase in cell mass observed in these experiments or in those of others (Pope \& Healy, 1933; Pappenheimer, 1947; Raynaud, Alouf \& Mangalo, 1959; Edwards, 1960) is accompanied by actual multiplication of bacteria remains uncertain. Nishida (1954) and Barksdale et al. (1961) reported that the viable count decreased to $20 \%$ or less while toxin was being formed. Edwards (1960), on the other hand, reported an experiment in which the number of viable bacteria increased fivefold during toxin formation, although in other experiments he was unable to obtain any consistent relationship between viable count and toxin yield. It should be stressed that the tendency of Corynebacterium diphtheriae strain $\mathbf{P W}$ no. $\mathbf{8}_{\mathbf{r}}(\mathbf{P d})$ to form clumps at the high population densities required (about $10^{10}$ organisms $/ \mathrm{ml}$.) makes reproducible and reliable viable counting difficult.

Barksdale et al. (1961) showed that when u.v.-irradiated cultures of toxigenic strains were placed in media of relatively low iron content, toxin release began somewhat earlier than in unirradiated cultures. They suggested that under the usual conditions for toxin production, as the bacterial iron content is decreased, phage multiplication is induced (autoinduction) and lysis of a proportion of the bacteria takes place. Whether or not a low bacterial iron content induced the change from prophage to vegetative phage, the present studies show conclusively that lysis occurs in too small a fraction of the bacteria to account for the amount of toxin released. In an experiment with bacteria labelled with ${ }^{14} \mathrm{C}$-phenylalanine, producing toxin in a medium containing unlabelled phenylalanine, less than $4 \%$ of the label, equivalent to only $80 \mu \mathrm{g}$. dry wt. bacteria, was found in the supernatant fluid at a time when $55 \mu \mathrm{g}$. unlabelled toxin had been liberated. It should be recalled that Yoneda \& Pappenheimer (1957) were unable to detect appreciable amounts of nucleic acid in culture filtrates of Corynebacterium diphtheriae strain $\mathrm{Cr}(\beta)$ until after toxin production was maximal and bacterial growth had ceased. When bacteria labelled with either ${ }^{35} \mathrm{~S}$-methionine or ${ }^{14} \mathrm{C}$-phenylalanine are placed in iron-free media containing unlabelled amino acids, the toxin formed is unlabelled except for a small fraction (probably preformed) released during the first hour. Thus diphtheria toxin is synthesized de novo from amino acids as has been shown to be the case with the $\beta$-galactosidase of Escherichia coli following addition of inducer (Hogness, Cohn \& Monod, 1955).

This work was aided by a grant from the National Science Foundation. 


\section{REFERENCES}

BarKSDALE, W. L. (1955). Sur quelques bactériophages de Corynebacterium diphtheriae et leurs hôtes. C.R. Acad. Sci., Paris, 240, 1831.

Barksdale, W. L. (1959). Lysogenic conversions in bacteria. Bact. Rev. 23, 202.

Barksdale, W. L., Garmise, L. \& Horibata, K. (1960). Virulence, toxinogeny and lysogeny in Corynebacterium diphtheriae. Ann. N.Y. Acad. Sci. 88, 1093.

Barksdale, W. L., Garmise, L. \& Rivera, R. (1961). Toxinogeny in Corynebacterium diphtheriae. J. Bact. 81, 527.

Barksdale, W. L. \& Pappenheimer, A. M., Jun. (1954). Phage-host relationships in non-toxigenic and toxigenic diphtheria bacilli. J. Bact. 67, 220.

EDWARDS, D. C. (1960). The growth and toxin production of Corynebacterium diphtheriae in submerged culture. J. gen. Microbiol. 22, 698.

Freeman, V. J. (1951). Studies on the virulence of bacteriophage-infected strains of Corynebacterium diphtheriae. J. Bact. 61, 675.

Groman, N. (1953). Evidence for the induced nature of the change from non-toxigenicity to toxigenicity in Corynebacterium diphtheriae as result of exposure to specific bacteriophage. J. Bact. 66, 184.

Hatano, M. (1956). Effect of iron concentration in the medium on phage and toxin production in a lysogenic, virulent $C$. diphtheriae. J. Bact. 71, 121.

Hogness, D., CoHn, M. \& Monod, J. (1955). Studies on the induced synthesis of $\rho$-galactosidase in Escherichia coli: The kinetics and mechanism of sulfur incorporation. Biochim. biophys. Acta, 16, 99.

Jope, E. M. \& O'Brien, J. R. P. (1945). Spectral absorption and fluorescence of coproporphyrin isomers I and III and the melting points of their methyl esters. Biochem. $J$. 39, 239.

Mueller, J. H. \& Miller, P. A. (1941). Production of diphtheria toxin of high potency on a reproducible medium. J. Immunol. 40, 21.

Nishida, S. (1954). C. diphtheriae. II. Specific characteristics of the growth curve of C. diphtheriae. Jap. J. med. Sci. Biol. 7, 495.

Pappenheimer, A. M., Jun. (1947). Diphtheria toxin. III. A reinvestigation of the effect of iron on toxin and porphyrin production. J. biol. Chem. 167, 151.

PaPpenheimer, A. M., Jun. (1955). The pathogenesis of diphtheria. Symp. Soc. gen. Microbiol. 5, 40.

Pappenheimer, A. M., Jun. \& Yoneda, M. (1957). A reinvestigation of the diphtheria toxin-antitoxin flocculation reaction using ${ }^{35} \mathrm{~S}$-methionine-labelled toxin. Brit. J. exp. Path. 38, 194.

Pope, C. G. \& Headex, M. (1933). Surface growth and toxin production by $C$. diphtheriae. Brit. J. exp. Path. 14, 87.

RACKER, E. (1950). Spectrophotometric measurements of the enzymatic formation of fumaric and cis-aconitic acids. Biochim. biophys. Acta, 4, 211.

Raynaud, M., Alouf, J. \& Mangalo, R. (1959). Croissance et toxinogénèse diphtériques en culture agitée, sur milieu synthétique. Ann. Inst. Pasteur, 96, 276.

Raynaud, M., Turpin, A., Mangalo, R. \& Bizzini, B. (1954). Croissance et toxinogénèse. Ann. Inst. Pasteur, 87, 599.

Raynaud, M. \& Relyveld, E. H. (1959). La réaction toxine-antitoxine diphtérique. Ann. Inst. Pasteur, 97, 636.

YoNedA, M. (1957a). Kinetic studies on the production of toxin by a toxinogenic strain of C. diphtheriae. Igaku Nisshin, 45, 727 (in Japanese).

YonEDA, M. (1957b). A new culture method designed for kinetic studies of diphtheria toxin production. Brit. J. exp. Path. 38, 190.

Yoneda, M. \& Pappenheimer, A. M. Jun. (1957). Some effects of iron deficiency on the extracellular products released by toxigenic and non-toxigenic strains of Corynebacterium diphtheriae. J. Bact. 74, 256. 